GIS - 理論と応用

Theory and Applications of GIS, 2012, Vol.20, No.1, pp.1-9

【原著論文】

\title{
東京区部における都市施設分布と年齢別人口構成の推移の関連性分析 \\ 鈴木 勉*・大城将範 ** \\ Analyzing transition of urban facilities distribution and age structure of population in Central Tokyo
}

Tsutomu SUZUKI*, Masanori OSHIRO**

\begin{abstract}
This paper aims to clarify the change of density of urban facilities in central Tokyo (ward area), and to analyze the change of density of urban facilities and its dependence on age structure of small district. We focus on age structure that have an influence on change of density of urban facility, and clarified its relationship. Day nursery, kindergarten, elementary school, junior high school, and hospital are taken up as urban facilities in this paper. We find out that the change in the density of each urban facility is partially explained by that in population density by using kernel density functions with appropriate radius.
\end{abstract}

Keywords: 都市施設（urban facility），年齢構成（age structure），人口（population），カーネ ル密度推定 (kernel density estimation), 東京区部（Tokyo ward area）

\section{1.はじめに}

自治体の財政悪化などを背景に，都市施設はその 効率的な管理運営が求められるようになってきてい る。人口の急増・急減は都市施設の不足や過剩を生 むため, 効率的な管理運営のためには, 都市の成長 管理を行って，こうした急激な変化を避ける方が望 ましい.

ところが，都市施設の中には，特定の年齢層を対 象としていて, 人口の急変がなくても地域の年齢構 成の大幅な変化によって施設需要が大きく変化する 場合がある. 例えば, 少子化により幼稚園や小中学 校の需要が廃校となるケースや，高齢化の進行によ り地域医療ニーズが増加し, より多くの病院が必要 となるケースがこれに当たる。

浅見（2006）は,「多様なタイプの住宅が供給さ れることにより, 多様な世带構成や年齢層, 社会階 層の人々が集まり, 時間の推移とともに世帯構成や 人口構成が大きく変化しない地域が実現できる。こ れによって特定年齢層に必要な施設の一時的な混在 や供給過剩現象を回避し, 公共施設の安定的・効率
的な利用を図ることができる」と述べている，上述 のような施設については, 年々変化する状況の下, 長期的な需要の増減を踏まえながら限られた財政資 金，施設ストックの中で最適な施設計画を行うこと が求められる。長期的な視点で見た場合，福祉施設 や教育施設は年齢層に敏感であり，多様なタイプの 住宅が供給されることで安定的な施設運用が可能と 考えられる。しかし，現実には，都心のマンション 立地で急に小学校の需要が高まるなど，年齢構成が アンバランスに変化することは珍しくない.

都市施設の立地には，地価や新規用地の確保可能 性などの他の要因にも影響を受けると考えられる. したがって, 人口の変化だけで都市施設の有無を記 述することはできないであろう。しかし，人口分布 に対応することが必要な施設分布を適切にコント ロールすべきであると考えられる。このためには, 人口密度で施設分布を部分的にでも説明可能なこと をまず確かめることが必要であり，さらに過去にど のような年齢別人口構成の変化が施設の新設・廃止 につながったかがわかれば，望ましい施設計画を考

* 正会員 筑波大学システム情報系（University of Tsukuba）

干 305-8573 茨城県つくば市天王台 1-1-1 E-mail：tsutomu@risk.tsukuba.ac.jp

** 学生会員 元筑波大学大学院システム情報工学研究科 (University of Tsukuba) 


\section{える上で有用である.}

そこで, 本研究では, 東京区部を対象として, 都 市施設分布の変化の状況を明らかにするとともに， 都市施設分布と年齢別人口構成の推移を小地域べー スで把握し，両者の関連性を分析することを目的と する，さらに，施設密度の時系列的な変化を対象年 齢の人口密度と対応させて, 空間的な対応関係を調 べることとする。

都市施設分布の変化を扱った既存研究としては, 貞広（1998）が駅周辺の商業施設についてカーネル 密度推定を用いて施設密度を計算し, 立地傾向の分 析を行っている。また, 同様に歳森ら (2002) は, カー ネル密度推定を適用して駅周辺の施設密度の異時点 間・施設種別間の分布の類似性を分析している. 本 研究では, これらの既存研究で行われてきた手法を 踏襲し, 施設密度の变化の傾向を把握する手法とし てカーネル密度推定を用いることとする。

\section{2. 東京区部における年齢別人口密度の変化}

今回対象とする東京区部（面積約 62,100ha）など の大都市中心部では, 高齢化が進む一方で, バブル 崩壊後の都心回帰によって, 一部の地域では人口の 急増が見られるところもある（大城・鈴木, 2009a, $2009 b)$. 本研究では, 国勢調査小地域集計 $(2000$ 年, 2005 年については総務省国勢調查ホームペー ジ, それ以前については東京都総務局統計部人口統 計課）の東京区部町丁目別年齢階級（5歳）別人口 デー夕（1980年・1985年・1990年・1995年・2000年・ 2005 年の 6 時点）を用いた。ここでは，年齢別人口 構成との関連性が深い都市施設として, 保育所・幼 稚園・ 小学校. 中学校・病院を対象とする. 各施設 に対応する年齢階級は，それぞれ保育所・幼稚園 0 $\sim 4$ 歳, 小学校 $5 \sim 9$ 歳, 中学校 $10 \sim 14$ 歳, 病院 60 歳以上とした。これらの都市施設の分布 (出典は 後述）と, 対象としている年齢層の 5 年間の人口密 度変化を表したのが, 図 1 および図 2 である。0〜 4歳の人口密度变化を見ると，1990～95年の期間 に若干増加の傾向を見せ，その後1995 年から区部 全体で増加に転じている。一方，5～9歳は1995～ 2000 年に部分的に増加し, 2000〜05年にかけて区
部全体で増加している. 10～14歳は 2000～05 年に 部分的に増加の傾向が見られる。このように, 各年 代層の人口変化の傾向には時間的ラグがあることが わかる，60歳以上については，中心部で減少がみ られることがあるものの，ほぼ区部全域で全期間を 通じて増加している.

\section{3. 東京区部における都市施設分布の変化}

一方で，主要な都市施設分布はどのように変化し てきているであろうか. 保育所については「福祉施 設等一覧」(東京都福祉保健局, 1980-2005), 幼稚園, 小学校, 中学校については「東京都公立学校一覧」 (東京都教育庁総務部, 1980-2005), 病院について は「東京都医療機関名簿」(東京都福祉保健局医療 政策部医療人材課，1980-2005）の紙媒体データに 依り，対象年は1980年・1985年・1990年・1995年・ 2000 年・ 2005 年の 5 年毎 6 時点を対象とした. 幼稚 園・小学校・中学校の対象は公立学校のみであり, 国立・私立は対象外とした。保育所については，児 童福祉法に基づいて設置されている認可保育所のみ を対象とし,2001年から東京都独自の制度である「認 証保育所制度」に基づいて設置された認証保育所は 対象としない，病院については，計画的に配置され ている大規模病院や数の多い小規模の診療所を除く ため, 「東京都医療機関名簿」に記載されている病 院のうち, 病床数 10 床以上 20 床未満のものを対象 とした，地理的分布は図 1 および図 2 に示した通り である. 表 1 は各施設の施設数の年度毎の推移を示 したものであるが, 区部全体としては，小学校・中 学校・幼稚園・病院は減少傾向, 保育所はほぼ横ば いであることがわかる。

\section{表 1 対象施設の施設数の推移}

\begin{tabular}{|l|r|r|r|r|r|r|}
\hline & 1980 年 & 1985 年 & 1990 年 & 1995年 & 2000 年 & 2005 年 \\
\hline 保育所 & 1014 & 1066 & 1070 & 1054 & 1054 & 1063 \\
\hline 幼稚園 & 279 & 285 & 275 & 250 & 250 & 210 \\
\hline 小学校 & 925 & 949 & 952 & 931 & 912 & 861 \\
\hline 中学校 & 407 & 427 & 433 & 432 & 424 & 406 \\
\hline 病院 & 314 & 276 & 240 & 218 & 179 & 163 \\
\hline
\end{tabular}




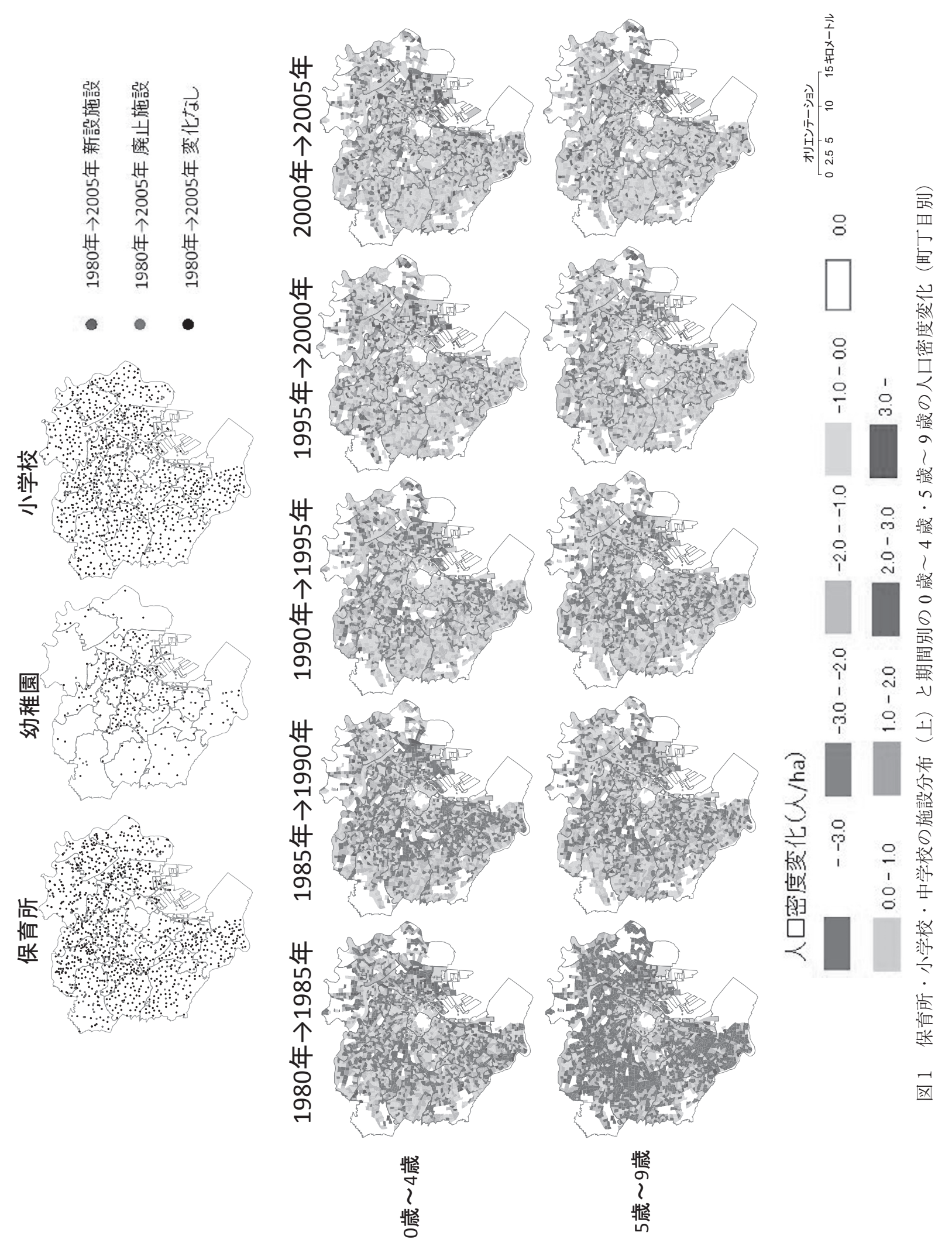



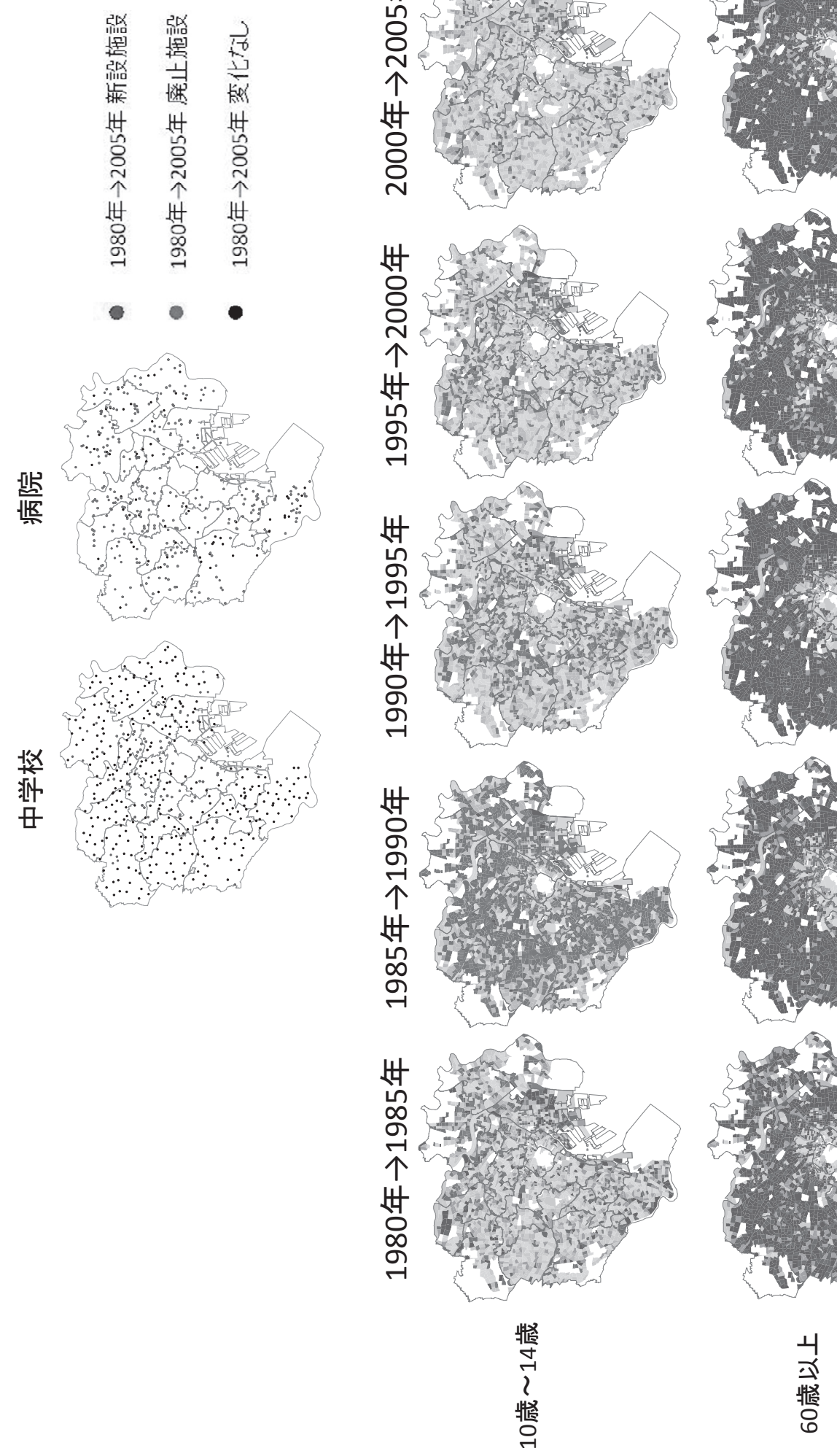
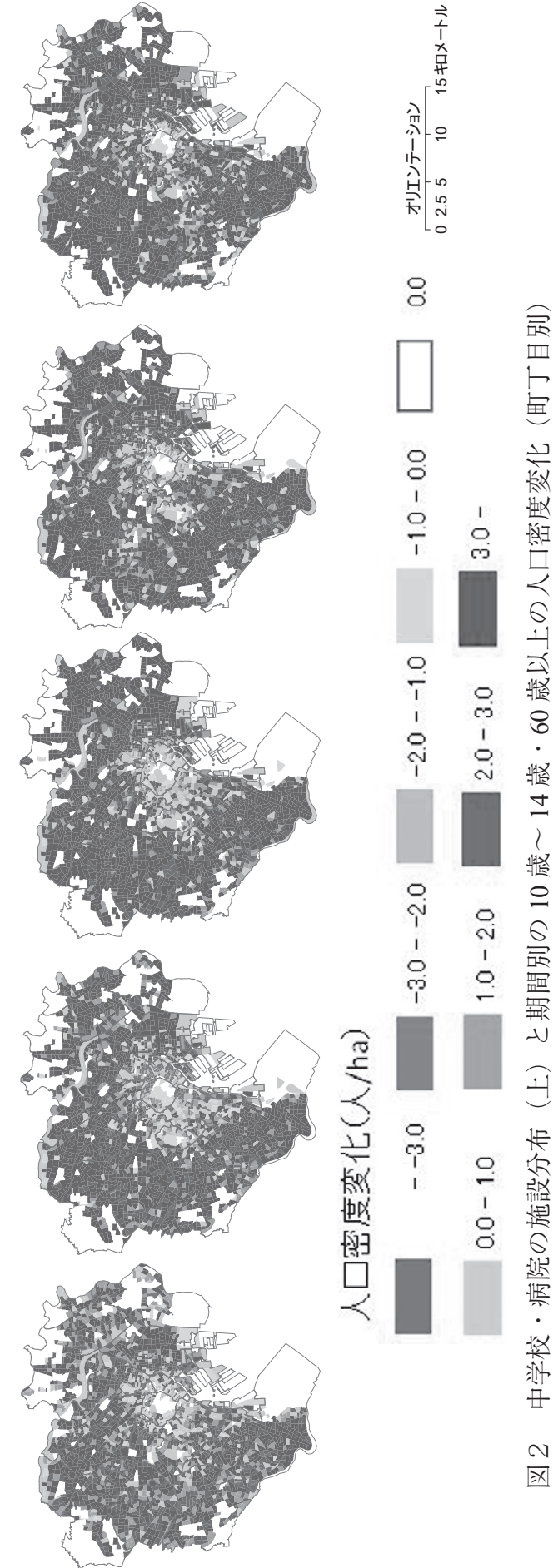

$8 \quad \stackrel{2}{2}$

101 芘

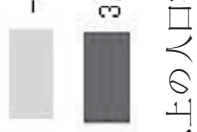

$\stackrel{1}{1}$

108

i

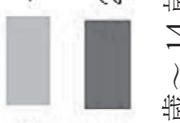

$\stackrel{i}{i} \stackrel{0}{6}$

○

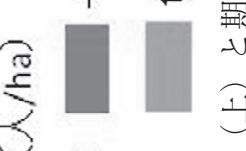

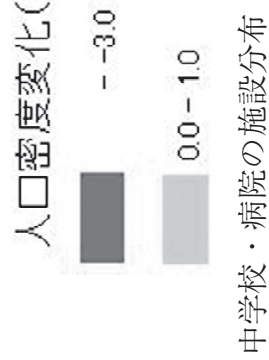

爫 
表 2 各集計単位の単位数·面積・人口

\begin{tabular}{|l|r|r|r|}
\hline 単位 & 集計単位数 & 平均面積 $\left(\mathrm{km}^{2}\right)$ & 2005年平均人口 $(人)$ \\
\hline 町丁目 & 2,571 & 0.182 & 2,794 \\
\hline 町 & 779 & 0.602 & 9,223 \\
\hline 小ゾーン & 249 & 1.884 & 28,853 \\
\hline 計画基本ゾーン & 113 & 4.151 & 63,579 \\
\hline
\end{tabular}

\section{4. 人口分布と都市施設分布の変化の関連性}

4. 1. カーネル密度推定法

人口分布の変化は町丁目単位のゾーン集計デー夕 であるが, 施設分布の変化はポイントデータであり, 関連性を直接計測することは難しい，そこで，施設 密度の変化の傾向を把握する手法としてカーネル密 度推定法を用いる。カーネル密度推定法は, ある事 象の生起点の分布から事象の確率密度を推定する方 法であり, 生起点毎にカーネル関数と呼ばれる関数 を置き，全てのカーネル関数の和で確率密度を定義 する. カーネル関数によって生起点の近傍には高い 確率密度が与えられる。どの範囲までを「近傍」と するかによって結果は異なる。 カーネル関数として は様々な関数形が用いられるが，貞広（1998）は平 面上の座標として得られた施設の位置を中心とし た 2 次元ガウス型カーネル関数を用いて, 施設の確 率密度を推定している. 種類 $i$ の施設の施設数を $n_{i}$, その $j$ 番目の施設の位置を $x_{i j}$ として, 近傍の大きさ のパラメータを $h_{i}$ とすると, ガウス型確率密度は以 下のように表すことができる。

$$
f(x)=\frac{1}{2 \pi h_{i}^{2} n_{i}} \sum_{j} e^{-\frac{1}{2 h_{i}^{2}}\left|x-x_{i j}\right|^{2}}
$$

今回対象としている施設は, 本来, 対象年齢の全 ての住民に公平にサービスを提供できるように立地 されるものであるが，現実には必ずしも理想的な場 所に立地している訳ではない，また，施設は基本的 にその場所まで赴いてサービスが提供されるもので あるため, 施設が提供するサービスは施設の立地場 所にのみにあると考えるよりも，立地場所を中心に その周囲に連続的に存在すると考えることができ る、このため，施設の立地をサービスを受けること のできる場所の分布と捉えて，これをカーネル関数 を用いて推計した。
4. 2. バンド幅と集計単位を考慮した施設密度と 人口密度の関倸

施設は，その種類毎にその規模やサービス範囲が 異なっている，例えば，表 1 に見るように，保育所 の数は幼稚園の数の $4 \sim 5$ 倍の数存在するが, これ はサービスを受ける人口がそれだけの開きがあると いうことではなく，保育所の施設規模が幼稚園のそ れよりも小さいことによる。これに応じて，保育所 のサービス範囲は幼稚園のそれよりも小さく狭いも のとなっていると考えられる，すなわち，前節で施 設の周りにサービスが連続的に分布していると考え る際に，その分布の広がりが施設毎に異なるという ことである

このことは, 施設の種類によって, どの程度のバ ンド幅を考慮すればよいかが異なることを意味して いる。また，施設密度と人口密度を地域別に集計す る際にどの程度の広がりの単位で集計するかが問題 となることを意味している。集計する単位が小さす ぎると人口密度のばらつきが大きすぎるため当ては まりが悪くなり，逆に集計する単位が大きすぎると 人口密度が均されてしまい, 地区の特徵が表現でき ずに当てはまりが悪くなることが考えられる。した がって，適切な集計単位が存在すると考えられる.

そのため, 本研究では人口密度と施設密度の集計 範囲を町丁目単位, 町単位 (○○丁目を一つに集計), パーソントリップ調査の小ゾーン, 計画基本ゾーン の4パターンを採用した，集計単位は自治体では大 きすぎるため，これより細かい単位として最も細か い単位である町丁目から，自治体を数個に分ける程 度の単位としての計画基本ゾーンまでを対象とし た、各集計単位の特徵を表 2 に示す。

全ての年度のデー夕を分析対象とし，それぞれの 集計単位の区域毎の各施設の需要に対応する年齢層 の人口密度を算出し, 後述の方法で計算した施設密 度 $\left[\right.$ 個 $\left./ \mathrm{km}^{2}\right]$ を被説明変数, 人口密度 $[$ 人 $/ \mathrm{ha}]$ 抢よび 年次のダミー変数（2005年を基本とし，それ以外 の年次のデー夕については各年次に該当する場合 1 とするバイナリ変数を用意）を説明変数として重回 帰分析を行った．重回帰分析の変数選択にはステッ プワイズ法を用いた。結果として推定された推定式 
の調整済決定係数が高いほど当てはまりがよいと考 えることとした。

ここで, 施設密度の計算は, 施設から密度サーフェ スを発生させ，その合計值を集計ゾーンの面積重心 で計測するという方法を採用した。 カーネル密度推 定のバンド幅は $100 ６, 000 \mathrm{~m}$ の間で $100 \mathrm{~m}$ 刻みで変 化させることとした，人口密度の計算も，人口の集 計ゾーンを単位として行い, ゾーンの面積重心を代 表点としてその地点の計測值とした。つまり, 施設 密度および人口密度の計測場所はどちらもゾーンの 代表点である面積重心であり，計測地点数はゾーン 数と同じである。

表 3 は, このような方法により, それぞれ各施設 の集計単位毎の最も調整済決定係数が高かったケー スのバンド幅と, ステップワイズ法によって有意水 準 5\%で採択された変数の非標準偏回帰係数を表し ている。保育所・小学校・中学校に関しては, 年次 ダミーの偏回帰係数が年を経るに従い減少傾向にあ るのは，施設密度が減少していることに対応すると 見られるが, 後述のように適合するバンド幅の大き い幼稚園と病院についてはこうした傾向は見られな かった。

\section{3. 東京区部における各都市施設の特徴}

本節では, 上述の分析方法を東京区部の対象施設 に適用し，施設毎の対象年齢総人口との対応関係と 影響範囲の違いを明らかにする。

保育所の決定係数は, 計画基本ゾーンで最も高く, そのときのバンド幅は $1,900 \mathrm{~m}$ となった。後述の小 学校に比べるとバンド幅が長い結果となり, 保育所 はより広域的な対象年齢層の人口分布と対応してい るといえることがわかる. 小ゾーンの場合の決定係 数も大差なく, やや狭域の人口分布との対応関係も よいことが窺える。

幼稚園については, 決定係数は小ゾーン集計の場 合に比較的高いが, 全体的に低く, 適切なバンド幅 は見つからないという結果になっている。良いモデ ルは構築できていないが, これは公立の幼稚園のみ を扱っており，施設数が少なく分布が偏っているた めであると思われる。東京区部は特に私立学校の果
たす役割は大きく，私立を考慮すればより良い結果 となることが期待される.

小学校についても, 決定係数は 0.2 未満であり, 幼稚園の場合よりは高いものの, 説明力の高いモデ ルは構築できていない. 全体の施設数が同程度の值 である保育所と比べても決定係数が低くなっている ことから, 小学校についてはエリアをカバーするよ うに均等に配置するように計画されていることに よって，人口分布にそれほど影響されない傾向に なっていると考えられる.

中学校は計画基本ゾーンで最も決定係数が高く なっており，バンド幅は $1,500 \mathrm{~m}$ とっている。計 画基本ゾーンでの決定係数やバンド幅は保育所と似 ているが, 中学校の場合は小ゾーンでの決定係数が 計画基本ゾーンに比べて低くなっている.

病院は, 計画基本ゾーンで最も決定係数が高くな り，最もよく適合するバンド幅は $4,100 \mathrm{~m}$ とった。 病院の場合は, 通院圈域が広く, 他の公共施設より もより広範囲の需要と対応していることがわかる.

比較的説明力の高かった施設の適合の良いバンド 幅は, 中学校 $1,500 \mathrm{~m}$, 保育所 $1,900 \mathrm{~m}$, 病院 $4,100 \mathrm{~m}$ となった。これが施設毎に異なることは, 施設の種 類によって，その圈域の広がりが異なることを意味 している。 また, 集計単位については, 計画基本ゾー ンや小ゾーンなどの比較的大きな集計単位の方が適 合する結果となっているが，己れは町丁目や町ほど の小さい集計単位では, 同一施設圈域の内部に複数 の集計単位が入ってしまい，圈域内でのばらつきを 説明できないためであると考えられる。

4.4. 東京区部における各施設密度の変化

以上では, 経年データをプールして年次ダミーを 説明変数に加えることによって一括して分析した が，時系列データが存在するので，前節で比較的良 い結果が得られた保育所, 中学校, 病院を対象に, 各施設に適合するバンド幅を用いて, 施設密度の時 系列変化を地図で表現する。そして, 図 1 ・図 2 の 対象年龃の人口密度の変化と対比してみることとす る.

罒 3 は各期間についての施設密度変化を表したも 
表 3 各集計地区単位における決定係数が最も高かった重回帰分析結果

\begin{tabular}{|c|c|c|c|c|}
\hline 保育所 & 町丁目 & 町 & 小ゾーン & 計画基本 \\
\hline パンド幅 & $1500 \mathrm{~m}$ & $1600 \mathrm{~m}$ & $1000 \mathrm{~m}$ & $1900 \mathrm{~m}$ \\
\hline 調整済決定係数 & 0.1359 & 0.1665 & 0.4690 & 0.4863 \\
\hline \multicolumn{5}{|c|}{ 咅変数の偏回慢係数 } \\
\hline （定数項） & 1.3491 & 1.2000 & 0.0379 & 0.0734 \\
\hline 人口密度 & 0.0784 & 0.0932 & 0.2290 & 0.2226 \\
\hline 1980年ダミー & 420 & 0.2980 & 0.7071 & 0.7088 \\
\hline 985年ダミー & 0.2483 & 0.3031 & 0.7373 & 0.7541 \\
\hline 1990年ダミー & 0.2538 & 0.3130 & 0.7587 & 0.7752 \\
\hline 1995年ダミ一- & 0.1958 & 0.2406 & 0.5576 & 0.5739 \\
\hline 000 年ダミー & 0.0843 & 0.1111 & 0.2246 & 0.2307 \\
\hline 中学校 & 町丁目 & 町 & ホゾーン & 計画基本 \\
\hline パンド幅 & $1900 \mathrm{~m}$ & $1500 \mathrm{~m}$ & $900 \mathrm{~m}$ & $1500 \mathrm{~m}$ \\
\hline 調整済決定係数 & 0.0765 & 0.1049 & 0.3164 & 0.4321 \\
\hline \multicolumn{5}{|l|}{ 各変数の偏回帰係数 } \\
\hline (定数項) & 0.6219 & 0.5690 & 0.1207 & 0.0526 \\
\hline 人口密度 & 0. & 0.0262 & 0711 & 0.0784 \\
\hline 1980年ダミ一 & & 0.12 & 85 & 0.3723 \\
\hline 5年ダミー & & & 4 & \\
\hline 1990年ダミー & 0.07 & 0.09 & 0.2508 & 0.2830 \\
\hline 1995年ダミ一- & 0.0483 & 0.0663 & 0.1653 & 0.1869 \\
\hline 2000年ダミー & & & & \\
\hline
\end{tabular}
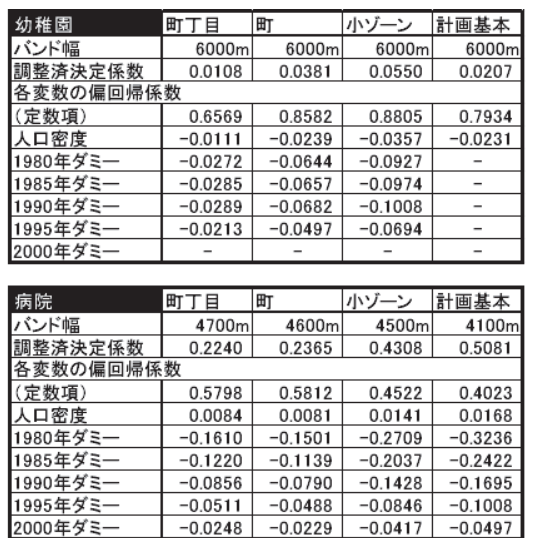

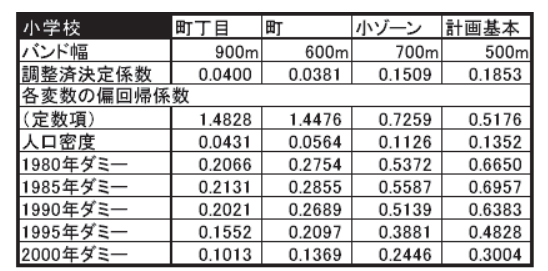

\begin{tabular}{|l|l|l|l|l|}
\hline 1995 年タミ一 & 0.1552 & 0.2097 & 0.3881 & 0.4828 \\
\hline 2000 年タミ一 & 0.1013 & 0.1369 & 0.2446 & 0.3004 \\
\hline
\end{tabular}
のである，施設密度を計算する際のバンド幅として は, 施設から密度サーフェスを発生させ，その中で も当てはまりの良い場合のバンド幅を採用すること とした。ただし, 幼稚園および小学校についてはバ ンド幅を決定する際の決定係数が低かったため, 分 析対象から除外した。

施設密度は，対象年齢の低い順に保育所から中学 校へと増加から減少に転じてきていることがわか る。保育所に関しては，1980～85年にかけて全体 で増加したが，その後1985～2000年にかけては減 少した. 2000〜05年にかけて再び周辺区で増加し ている。

中学校については, 1980～85年にかけては小学 校と同様に周辺区で増加傾向にある。その後あまり 変化がない期間が続いた後，1995～2005年にかけ て台東区・新宿区付近で大きく減少を見せている。

病院については周辺部の一部を除いて区部全体で 減少傾向にあることがわかる。

図 1 ・図 2 の人口密度の変化との対応を見てみよ j.

まず，保育所と対応する 0 ～歳人口分布の変 化を見ると, 1980年からは既に減少していたが, 1995 年頃を境に人口密度の増加している町丁目が 目立ってくる。これに対し, 保育所の密度は1980 〜 85 年は全体的に増加傾向にあり, 85 年以降に減 少傾向に入ったものの, 逆に 1995 年以降もその減 少傾向が続いていることが読み取れる.このように, 人口分布の変化との対応が必ずしも同期できていな いことがわかる。このことは，前節での適合があま
り良くないことの一つの理由になっている可能性が ある。

中学校と対応する $10 \sim 14$ 歳人口については, 1985～90年に急減しているが, 中学校の密度の方 はかなり遅れて 2000〜05 年にかけて施設密度が大 きく減少していることがわかる。

病院については，バンド幅が $4 \mathrm{~km}$ を超えるという 結果となったため, 施設密度の変化が区部内で明確 な分布を持っておらず，こちらも明確な分布が見ら れず全体的に増加している60歳以上の人口密度と 対応するという結果になっていると考えられる。

以上のように，前節で算出されたバンド幅を用い て, 施設密度の変化と人口密度の変化を対応させる と, 変化の関係が時間的に必ずしも同期していない ことがわかる。都市計画の観点からは，こうした時 間的なずれをなくすための方策や，変化の幅が一定 の範囲に収まるような年齢構成の実現といった方策 が求められると言える。

\section{5. まとめと今後の課題}

本研究では, 都市施設として保育所・幼稚園・小 学校・中学校・病院に着目して, 時系列データを分 析し, 施設密度分布と対象年齢の人口密度の変化の 関連性を分析した。東京区部について分析した主な 結果は以下の通りである。

(1)計画基本ゾーン単位・ 小ゾーン単位・町単位・ 町丁目単位についてバンド幅毎に重回帰分析を 行い, 施設密度と, その施設の対象年歯令の人口 密度の関係性を分析した。その結果, 保育所, 

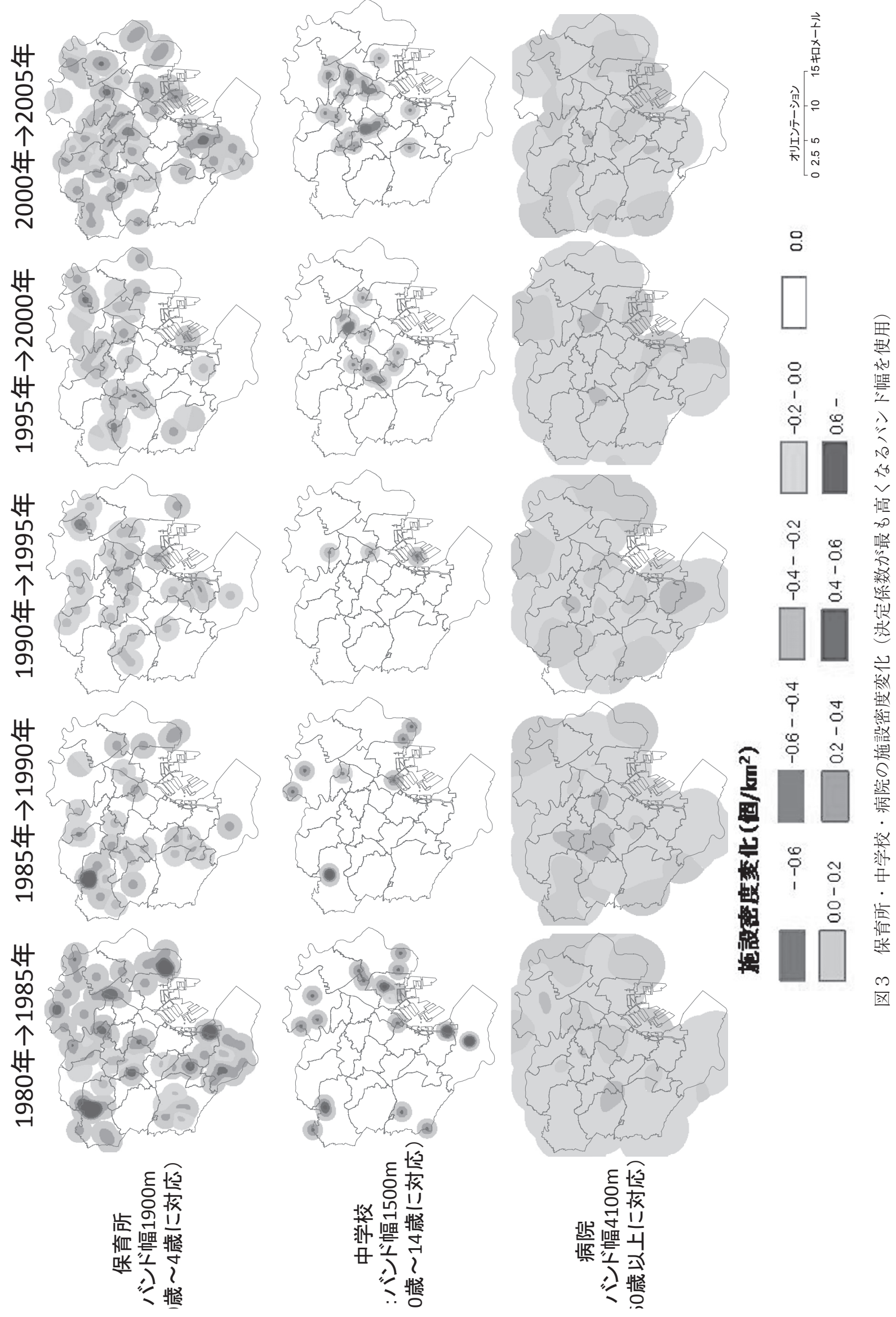

a 
中学校, 病院については, 説明力は高くないも のの, 集計単位とバンド幅を適切にとることに よって，ある程度の相関を記述できることが明 らかとなった。

(2)上のバンド幅を用いて, 施設密度の時系列的な 変化傾向を人口密度変化と対照させることによ り,両者の変化の関係性を分析した。その結果, 必ずしも両者の変化が同期していないことが確 認された。このことは，人口密度の変化に合っ た施設計画や，人口密度変化の幅を小さくする 施策の必要性を示唆する。

具体的な施策としては, 多様な階層の人口が定着 するように多様な夕イプの住宅供給を行ったり，時 代のニーズに応じて転用可能な建築物としたりする ことが挙げられる.

本研究では, 施設の規模を全て同一と考え, 同一 のカーネル密度関数で分析を行ったが, 現実には規 模はまちまちであり，それによって施設の圈域や影 響範囲の大きさも多様であると考えられる。また， 本研究の分析結果は, 町丁目やゾーンといった集計 単位の大きさと形状に依存しており，異なる集計方 法を用いると結果も異なったものとなるという久点 を持っている。したがって, 今後の課題としては, 都市施設の規模（収容人数など）を考慮したカーネ ル密度推定を行うことや, 集計する単位を連続的に 変更した分析，時間的なラグの定量的な分析を行う 等が挙げられる。また，上述の具体的な施策がもた らす効果の計測への応用も挙げられよう.

\section{謝辞}

本研究は, 日本学術振興会科学研究費補助金およ びシンフォニカ統計 GIS 研究助成による研究成果の 一部である。また匿名の査読者には多くの貴重な助 言を頂いた。ここに記して感謝の意を表する.

\section{参考文献}

東明佐久良・佐藤裕人 - 小坪宏則（1994）携帯型地 理情報システムの開発.「GIS - 理論と応用」, 3 (1), $1-8$.

福井弘道(1996) GISを用いた都市・地域の解析、『GIS ソースブック』(高阪宏行・岡部篤行編), 古今書院, 336-345.

浅見泰司（2006）『住環境－評価方法と理論 $-』 ，$ 東 京大学出版会.

貞広幸雄（1998）大都市における商業空間構造の分 析手法,「都市計画」, Vol.47, No.5, pp.74-79.

歳森 敦・五弓裕文・勅使川原将吾・谷村秀彦 (2002) カーネル法で推定した密度曲線の類似性に基づく市 街地の地域施設分布の変化，「日本建築学会計画系 論文集」，No.552，pp.133-139.

総務省国勢調查ホームページ。 < http:// www.stat. go.jp/data/kokusei/2005/index.htm>

東京都教育庁総務部（1980-2005）『東京都公立学校 一覧』。

東京都福祉保健局（1980-2005）『福祉施設等一覧』. 東京都福祉保健局医療政策部医療人材課（19802005）『東京都医療機関名簿』.

東京都総務局統計部人口統計課『東京都区市町村町 丁別報告』，国勢調查各年版.

大城将範 ·鈴木 勉 (2009a) 年齢別人口構成比率の 変化を用いた地区分類,「2009年オペレーションズ・ リサーチ学会春季研究発表会アブストラクト集」, pp.10-11.

大城将範・鈴木 勉（2009b）年齢構成の変化からみ た地区分類と住宅開発との関連性 - 1970年〜2005 年の東京都区部を対象として一,「都市計画論文集」, Vol.44, No.3, pp.727-732.

（2010年5月 27日原稿受理, 2012年3月 12 日採用決定, 2012年 5 月 24 日デジタルライブラリ掲載) 